\title{
Työnohjaus projektimaisessa työssä
}

\author{
1 \\ Projektinomaisuus on tullut osaksi organisaatioiden arkipäivää ja \\ muuttanut samalla organisaatioiden ja yksilöiden perustehtävän \\ dynaamisemmaksi ja vaikeasti määriteltäväksi. Pohdin \\ artikkelissa, millä tavoin projektimaista työtä voidaan tukea \\ työnohjauksen keinoin ja miten projektimaisen työn omaa \\ apuvälineistöä voidaan valjastaa työnohjauksen tarpeisiin.
}

SUOMALAINEN TYÖELÄMÄ on viime vuosikymmeninä muuttunut tietointensiiviseksi, teknologiakeskeiseksi ja nopealiikkeiseksi, ja organisointitavat ja -rakenteet ovat samalla kehittyneet. Työelämän muutoksia on käsitelty paljon negatiivisessa valossa (Seppänen 2004; Siltala 2004; Julkunen 2008), mutta dynaaminen ja markkinamekanismein säädelty työ voidaan nähdä myös mahdollisuutena hajauttaa vastuuta ja toimia itseohjautuvasti (Malone 2004). Eräs muutosten ilmentymä on työn ja työyhteisöjen "projektisoituminen" (Malone 2004), toisin sanoen projektien eli tilapäisten, tavoitteellisten ja sisällöltään rajattujen tehtävien varaan organisoitu työ on lisääntynyt osana yksilöiden ja organisaatioiden perustehtävää. Projekteilla on vuosisatojen historia teollisessa työssä (Artto et al. 2006), mutta projektimaisen toiminnan vaikutuksia työelämässä ymmärretään edelleen sangen huonosti.
Tämän artikkelin lähtökohtana on ajatus siitä, että työtä ja työssä kehittymistä voidaan tukea työnohjauksella, työnohjaajan ja ohjattavan vuorovaikutuksessa. Työnohjauksella tarkoitetaan "erityiskysymysten asiantuntijan tai kokeneemman työntekijän antamaa ohjausta ja tukea oman työn arvioinnissa, työongelmien erittelyssä ja ratkaisemisessa sekä tarvittavien toimenpiteiden suunnittelussa" (Niskanen et al. 1988).

Aikaisempi työnohjauskeskustelu ei juurikaan ole puuttunut moderniin projektimaiseen työhön työnohjauksen kontekstina. Kysynkin, millä tavoin projektimaista työtä voidaan tukea työnohjauksen keinoin. Rajaudun ensisijaisesti yksilöohjaukseen työtehtävissä, joissa projekteilla on merkittävä osuus, joskin samat ilmiöt voivat päteä myös ryhmä- ja yhteisöohjauksessa sekä töissä ja työyhteisöissä, joissa projektit ovat toissijaisia. Aihepiiri voi koskea teolli- 
suutta, muuta yksityissektoria ja julkishallintoa, sillä projektimainen työ on lisääntynyt kaikilla sektoreilla. Yhteistä eri aloilla on se, että työ on muuttunut dynaamisemmaksi ja perustehtävää voi olla vaikea määritellä. Käsittelen projektimaisen työn erityispiirteitä, jotka saattavat kohdentaa erityisvaatimuksia työnohjaukseen alasta riippumatta.

Aiempi työnohjauskirjallisuus on käsitellyt työelämän projektimaistumista kriittisesti. Jatkuvat muutokset ja projektit on käsitelty kuormituksen ja haitan lähteinä, ne ovat olleet häiriö ja kiusa "normaalissa” työssä ja niistä on haluttu päästä eroon. Kuitenkin työelämän muuttumisen vuoksi olisi tarpeen löytää niitä konkreettisia keinoja, joilla ihmisiä tuetaan jatkuvassa muutoksessa ja autetaan heitä selviytymään, kasvamaan ja kehittymään myös projektimaisessa työssä. Tämä artikkeli käsittelee projektimaisen työn ohjaustarpeita ja erityisesti niitä ohjauksen katvealueita, joita tavanomaiset projektinhallinnalliset ohjausjärjestelyt eivät täytä. Tarkoituksena on selvittää, millä alueilla työnohjausta voitaisiin soveltaa projektimaisen työn tarpeisiin ja mahdollisesti tunnistaa yksilöohjauksen sellaisia keinoja, joilla projektimaisen työn yksilöohjausta voidaan täydentää.

\section{PROJEKTIMAINEN TYÖ MODERNISSA TYÖELÄMÄSSÄ \\ Työelämän viimeaikainen muutos}

Suomalainen työelämä on aiemmin paljolti rakentunut tayloristisen työn osittamisen ja sitä kautta hierarkkisen organisoitumisen varaan. Nykyisessä modernissa kansainvälistyvässä työelämässä tietotekniikan käyttö on kuitenkin monilla tavoin uudistanut organisoitumista. Malonen (2004) mukaan viestinnän hinnan aleneminen ja sitä kautta helposti ja ilmaiseksi saatavilla oleva tieto vapauttaa organisaatiot keskitetyistä hierarkioista löyhempiin hierarkioihin, kohti demokraattisempaa organisoitumista ja jopa vapaita markkinoita. Moderni työelämä onkin hajautumassa: itseorganisoituminen, osallistuminen, vertaisverkostoituminen ja sisäinen yrittäjyys korvaavat keskitettyjä ja vahvoja järjestelmiä.

Modernissa työelämässä on monia merkkejä siitä, että uusi teknologia ja uusi kansainvälinen avoimuus järjestää työn organisointia uudella tavalla. Malone (2004) korostaa esimerkiksi päätöksenteon hajautumista organisaatioiden alemmille tasoille ja tätä kautta organisaatioiden sisäisten markkinoiden syntymistä tiedon ja sen vaihdannan keinoin. Samalla kun työelämän makrotasolla on puhuttu teknologistumisesta, ikääntymisestä, globaalistumisesta, kapitalisoitumisesta ja ekologisten arvojen korostumisesta, mikrotasolla mahdolliseksi on tullut yritysten sisäiset, tietoon perustuvat markkinat, joissa arvokkaita asioita tehdään väliaikaisina, jopa kilpailtuina sopimustöinä.

Työelämään ja sitä kautta työhön liittyvä muutos on toki käynnistynyt jo aiemmin ja siitä on kirjoitettu Suomessakin paljon (esimerkiksi Seppänen 2004; Siltala 2004; Julkunen 2008), mutta kirjoittamisen sävy on usein ollut muutoksia kritisoiva eikä sellaisenaan ole edistänyt työelämän mielekkyyden myönteistä kehittymistä.

Edellä mainittu kuva modernista työelämästä viittaa siihen, että organisaatioiden perustehtävä on muuttumassa radikaalisti sen takia, että tieto on nykyaikaisten teknologioiden ansiosta ilmaiseksi suunnilleen kaikkien saatavilla (Malone 2004). Organisaatioiden perustehtävää ei välttämättä voi enää rajata tietyn tiedon tai osaamisen omistajuus, vaan perustehtävä itsessään saattaa muuttua jatkuvasti tai liittyä muuttuviin tapoihin hyödyntää tietoa tai osaamista. Organisoituminen ei enää voi rakentua historiassa tehdyn työn osituksen ja hierarkian varaan ja staattiseksi, vaan muuttuu dynaamisemmaksi ja väliaikaiseksi, käytännössä projektimaiseksi (Pinchot \& Pinchot 1993).

Tämän artikkelin keskeisenä oletuksena on, että organisaation perustehtävä on dynaaminen, sitä ei pysty määrittelemään selkeästi eikä täydellisesti yhdellä ajanhetkellä ja tästä perustehtävän dynaamisuudesta ja määrittelemättömyydestä huolimatta organisaation palkattujen jäsenten pitäisi pystyä toimimaan organisaation yhteiseksi eduksi. Oletuksena on myös, että nykyisessä työelämässä yksilöiden työ on jatkuvasti muuttuvaa ja enemmän tai vähemmän projektimaista. 


\section{Projektimainen työ}

Projektimainen työ tarkoittaa sellaista työtä, jonka keskiössä on yksi tai useampia projekteja. Määritelmällisesti projekti voi merkitä A) ennalta märïitettyyn päämäärään tähtäävää monimutkaista tehtäväkokonaisuutta, B) väliaikaista organisaatiota, joka on muodostettu suorittamaan päämäärään tähtäävä tehtävä tai C) ongelmaa, joka on aikataulutettu ratkaistavaksi (ks. Artto et al. 2006). Kyse on siis tilapäisestä, tavoitteellisesta ja sisällöllisesti rajatusta tehtävästä, joka edellyttää omaa organisointiaan. Esimerkiksi taloja, laivoja ja tuotantolinjoja rakennetaan projekteina, uusia tuotteita ja palveluita kehitetään ja vanhoja parannellaan projekteina, organisaatiot usein muutetaan projekteina, ja yritysjärjestelyt - yritysostot, fuusiot, divestoinnit toteutetaan projekteina. Entistä enemmän myös julkishallinnon toiminnassa on mukana erilaisia projekteja: monenlaiset uudistuk-

"ON TARPEEN LÖYT $\ddot{A} \ddot{A}$ NitT $\ddot{A}$ KONKREETTISIA KEINOJA, JOILLA IHMISI $\ddot{A}$ TUETAAN

JATKUVASSA MUUTOKSESSA

JA AUTETAAN HEIT $\ddot{A}$ SELVIYTYM $\ddot{A}$ ÄN, KASVAMAAN JA KEHITTYM $\ddot{A} \dddot{A} N$ MYÖS PROJEKTIMAISESSA TYÖSS̈̈." huomio kiinnittyy tehtävään, aikaan, työn toteuttavaan ryhmään ja työn aikaansaamaan siirtymään (Lundin \& Söderholm 1995). Tehtävä on projektin olemassaolon tarkoitus ja se säätelee työtä ja tekemistä projektissa. Se on kiinteästi sidoksissa projektilta odotettuun hyötyyn ja päämäärään. Aika on projekteissa rajattu: projekteilla on alku ja loppu ja ennalta suunniteltu kesto. Aika on myös arvokasta, sillä sen kuluminen projektissa vaikuttaa projektin hyötyjen toteutumiseen. Ryhmä, sen sitoutuminen ja taidot tarvitaan suorittamaan projektin tehtävä. Ryhmän jäsenet voivat tulla eri puolilta organisaatiota tai jopa muista organisaatioista, mutta ne organisoituvat väliaikaisesti projektissa ja tuovat ryhmään ja projektin hyötyihin oman erityisen näkökulmansa. Siirtymä tarkoittaa sitä muutosta, joka projektissa pitäisi saada aikaiseksi ja jolla väliaikainen organisaatio tekee itsensä tarpeettomaksi projektin kuluessa. (Lundin \& Söderholm 1995)

Nämä yksittäisten projektien ominaispiirteet toteutuvat ainutkertaisella tavalla kussakin projektissa, vaikka niihin voi sisältyä toistuvuutta ja samankaltaisuutta projektista toiseen. Ne myös antavat selkeän vihjeen siitä, että projektien johtamisessa ja ohjauksessa keskeisellä sijalla on tilapäinen muutos ja muutoksen johtaminen ja ohjaus. Projektit kohdentavat sekä projektiryhmän jäseniin että projektipäälliköihin monenlaisia osaamisvaatimuksia (Vartiainen et al. 2003).

Projektimaisessa työssä yksittäisen projektin lisäksi korostuu muita ilmiöitä, jotka liittyvät projektien samanaikaisuuteen ja niiden muodostamaan jatkumoon sekä niiden organisointiin osana pysyvän emo-organisaation toimintaa (Engwall 2003). Ensinnäkin erilaiset organisointimuodot kuten matriisiorganisaatiot liittävät tilapäisiksi tarkoitetut projektit emo-organisaation pysyviin rakenteisiin. Omia vaatimuksiaan projektiin kohdistavia emo-organisaatioita 
saattaa useamman toimijan projekteissa olla useampia (Artto et al. 2008). Toiseksi informaatiotekniikka on tuonut projektimaiseen työhön etätyön, virtuaalisen työn ja mobiilin työn mahdollisuuksia, jotka ovat tehneet kansainväliset projektit tavanomaiseksi sekä samalla liittäneet työtä ihmisten arkeen ja hämärtäneet työn ja vapaa-ajan välisiä rajoja (Vartiainen et al. 2005). Kolmanneksi projektien samanaikaisuus on tehnyt mahdolliseksi ja jopa välttämättömäksi sen, että ihmiset toimivat useammissa projekteissa rinnakkain (Zika-Viktorsson et al. 2006). Voidaankin puhua moniprojektityöstä, jossa ihmisillä on useampia samanaikaisia projektiryhmäjäsenyyksiä. Neljänneksi organisaatioiden välinen yhteistyö projekteissa on merkinnyt monimutkaisia sidosryhmäsuhteita, ts. projektialihankintaa, teknistä sopimustyötä ja strategisia kumppanuuksia, joissa projektit laajenevat "moniryhmäprojekteiksi" tai toisinaan hyvinkin laajoiksi, sopimuksin säädellyiksi projektiverkostoiksi (Aaltonen 2010; Ahola 2009). Eräät projektit ovatkin siis useamman sidosryhmän tai emo-organisaation yhteisiä tehtäviä, joiden päämääristä, sisällöistä ja toteutustavoista neuvotellaan useamman organisaation kesken. Kuvassa 1 summeeraan joitakin erityisyyksiä, joita projektit ja niiden moninainen ympäristö tuovat nykyaikaiseen projektimaiseen työhön.
Edellä mainitut matriisiorganisoituminen, etätyö ja sitä kautta hämärtyvät työn ja vapaa-ajan rajat, moniprojektityö ja projektialihankinta ovat esimerkkejä projektimaisen työn arkisista erityispiirteistä. Nämä erityispiirteet aiheuttavat projektimaiseen työhön haasteita ja rasitteita (esimerkiksi Dietrich 2007; Lehtonen \& Martinsuo 2009; Zika-Viktorsson et al. 2006) ja kohdentavat sen johtamiseen ja ohjaukseen vaatimuksia, joita ei välttämättä perinteisessä johtamis- ja ohjauskirjallisuudessa käsitellä. Lisäksi oman haasteensa voi tuoda se, millainen asema projektimaisella työllä on annettu yksilöiden toimenkuviin ja työn tavoitteenasetantaan; toisin sanoen onko projektit tunnustettu ja mitoitettu keskeisenä työn sisältönä vai tehdäänkö projektit "otona" (oman toimen ohessa) sitten, jos muut työt antavat myöten.

\section{Projektimaisen työn ohjaukselliset erityispiirteet}

Modernissa työelämässä työn organisointi, johtaminen ja ohjaus on monilta osiltaan erilaista kuin aiemmin, ja samalla käsitys työstä ja ihmisestä on muuttunut. Malonen (2004) mukaan käskemisen ja kontrolloinnin sijasta tarvitaan koordinointia ja kultivointia. Myös Pinchot ja Pinchot (1993) kuvailivat muutosta byrokraat-
Kuva 1. Projekti ja sen kytkennät kohdistavat moninaisia vaatimuksia nykyaikaiseen projektimaiseen työhön.
Teollisuusala ja yrityksen muu laajempi toimintaympäristö

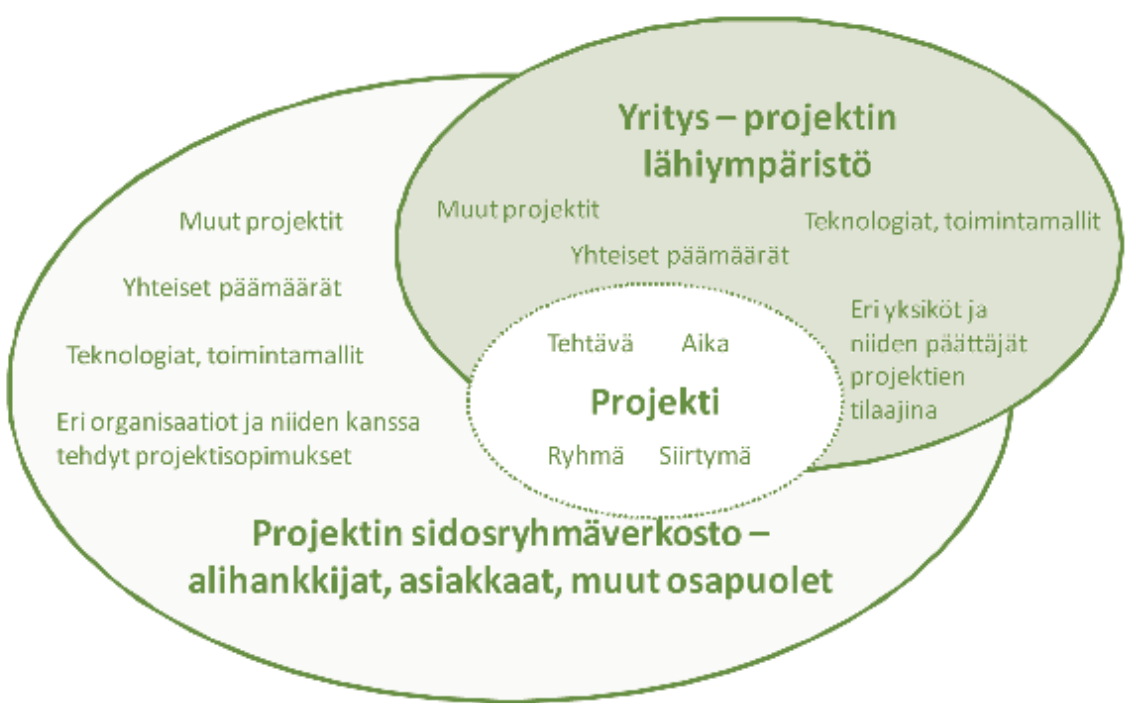


tisesta organisoinnista demokraattiseen ja korostivat yhteisen tahtotilan sekä vertais- ja itseohjauksen merkitystä modernin työn ohjauskeinona. Nykyaikaisessa johtamisessa korostuu siis tarve toimia tavoitteellisesti ja muuttuvan asiakastarpeen mukaisesti, itse- ja vertaisohjautuen ja verkostona.

Taustalla sekä Malonen että Pinchotin ja Pinchotin kuvaamissa muutoksissa on oivallus siitä, että työntekijät ovat tietäviä ja osaavia (eivätkä tietämättömiä, osaamattomia), ihmiset haluavat tehdä monia asioita (eivätkä toistaa jatkuvasti yhtä tehtävää samalla tavalla), ihmiset tekevät yhdessä töitä (eivätkä yksin), ihmiset toimivat teknologian parissa (eivätkä vain ihmisten), valta on asiakkailla (eikä johtajilla) ja työ jakautuu väliaikaisiin projekteihin (eikä pysyviin funktioihin).

Modernin työelämän ohjauksen kohteena oleva yksilö on näin ollen nähtävä taitavana, yritteliäänä, valtaistettuna ja omasta menestymisestään vastuussa olevana tekijänä. Samalla työ on nähtävä väliaikaisena, tavoitteellisena, ryhmämäisenä ja muuttuvana kokonaisuutena, jossa yksilön roolia ei välttämättä pysty ennakolta märïttämään. Projektimainen työ merkitsee, että yksilöllä ei välttämättä ole yhtä tiettyä esimiestä, joka säätelisi työtä, vaan työtä johtavia tahoja voi olla useampia ja he voivat olla eri henkilöitä kuin varsinainen esimies (toisin sanoen palkkaa maksavan organisaation virallinen edustaja). Yksilö saattaa toimia työssään useamman organisaation projektimaisissa tehtävissä esimerkiksi sopimustyön kautta, joten organisaation ja sitä kautta yksilön perustehtävä ei ole aina sama. Perustehtävä ja yksilön suhde organisaatioihin saattaa myös muuttua jatkuvasti, ja yksilön on itse oivallettava työn ja tavoitteiden ajankohtaisia merkityksiä osana muuttuvaa verkostoa. Käsitys työurasta on niin ikään dynaaminen, eteneminen ei tapahdukaan hierarkkisilla portailla, vaan pikemminkin kokeilemalla ja oppimalla (Ibarra 2003).

Yhteenvetona tämän luvun pohdinnoista, projektimainen työ ja siihen sisältyvät oletukset kohdistavat työnohjaukseen erityisiä vaatimuksia, jotka pitäisi ottaa huomioon niihin liittyvässä ohjauksessa. Muun muassa:
- organisaation perustehtävä on jatkuvassa muutoksessa ja se ei ole välttämättä tiedossa joka hetkellä,

- yksilön tehtävä on muuttuva ja moninainen ja se ei ole välttämättä tiedossa joka hetkellä,

- yksilö saattaa tehtävässään palvella useampia tavoitteita, organisaatioita ja työnjohtajia (ts. useampia eri organisaatioiden perustehtäviä) samanaikaisesti, ei vain yhtä,

- yksilön toiminta vaikuttaa vertaisiin ja laajempaan verkostoon (myös yli organisaatiorajojen) monilla ennakoimattomilla tavoilla, ja

- nykyaikaisten organisaatioiden keskeisiä ja vaikeitakin suhteita syntyy ihmisten ja teknologian välille, ei siis vain ihmisten kesken.

\section{TYÖNOHJAUS PROJEKTIMAISESSA TYÖSSÄ}

\section{Ohjauksen merkitys ja vaje}

Projektimaisessa toiminnassa on tavanomaista, että jokaista projektia johtaa projektipäällikkö, jonka tehtäviin kuuluu projektin tavoitteiden mukaisen työn johtamisen lisäksi ryhmän ja siinä olevien yksilöiden johtajuus. Johtajuus pitää sisällään sekä suunnan näyttämisen ja ihmisten toimintaan vaikuttamisen että motivoimisen ja innostamisen (Artto et al. 2006). Lisäksi jokaiselle projektille on nimetty ylempää johtoa, asiakasta tai oleellista asiantuntijuutta edustava valvoja tai, etenkin suurissa projekteissa, jopa kokonainen johto- tai ohjausryhmä. Valvojan tai johto- tai ohjausryhmän rooli keskittyy useimmiten projektilla tavoiteltujen hyötyjen varmistamiseen ja projektin suunnitelman mukaiseen toteuttamisen valvontaan, mutta niihin kohdistetaan myös tuen antamisen, jatkuvan seurannan ja "projektipäällikön sparraajan” odotuksia (Artto et al. 2006). Projekteista riippumatta jokaisella projektiin kuuluvalla on organisaation johtamisjärjestelmän mukaisesti lisäksi esimies, joka vähintäänkin asettaa, seuraa ja valvoo omaan linjaorganisaatioyksikköön kuuluvien yksilöiden tavoitteita ja suuntaa yksilöiden kehittymistä, mutta useimmiten myös ohjaa pitkäjänteisemmin yksilöiden osaamisen ja toimenkuvien kehittymistä. Kuva 2 havainnollistaa projektien keskeisiä osapuolia ja niiden roolia projektien ohjauksessa. 
Kuvassa 2 mainitaan lisäksi henkilöstöhallinto (HR), joka hallinnollisen roolinsa ohella usein tarjoaa tai koordinoi koulutus- ja kehityspalveluita myös projekteille. Suurissa organisaatioissa henkilöstöhallinto- tai henkilöstönkehitysyksikkö saattavat tarjota projektinhallinnan koulutusohjelmia, projektipäällikkötapaamisia, mahdollisuuksia projektinhallintaosaamisen sertifiointiin tai jopa projekteihin liittyvän urapolun. Myös mentorointia saatetaan soveltaa projektiammattilaisten keskuudessa. Toisinaan tällaisia tehtäviä varten on perustettu erillinen "projektitoimisto", joka tukee ja ohjaa projekteja ja koordinoi toimintaa eri projektien kesken. Varsinaisesta työnohjauksesta projektitoiminnassa ei vielä juurikaan ole puhuttu.

Jos jo pelkästään projektinhallinnan perusorganisointi sisältää monenlaisia ohjausulottuvuuksia, herää kysymys, mikä sija ja merkitys työnohjauksella voisi olla. Tämän merkityksen ymmärtämiseksi on tunnistettava ne katvealueet, joille organisoidut ohjausjärjestelyt eivät ulotu. Tällainen vaje löytyy projektien epävarmasta ja monimutkaisesta toimintaympäristöstä, jossa projektipäälliköt ja projektiryhmän jäsenet saattavat kohdata useita ristiriitaisia johtamis- ja ohjausviestejä ja joutuvat tekemään omia päätelmiään tällaisen ristiriitaisen tiedon va- rassa. Projektimaisen työn erityispiirteenä korostui toiminnan tilapäisyys, toimintakentän avautuminen vahvasti oman organisaation ulkopuolelle sekä dynamiikka ja vajavainen tieto työn, organisaation ja koko verkoston tasolla. Nämä projektimaisen työn erityispiirteet kyseenalaistavat projektien tavanomaiseen ohjaukseen liittyvät oletukset esimerkiksi tavoitteiden, työn, työsuhteen, työnjohdon ja organisaation perustehtävän pysyvyydestä ja märiteltävyydestä.

Vaikka projektipäälliköt ja projektiryhmäläiset saisivat projektityöhönsä koulutusta, työvälineitä ja käytännöllisiä menetelmiä, he eivät voi olettaa pärjäävänsä epävarmassa ja monimutkaisessa ympäristössä vain teknisellä ja rutiininomaisella työtavalla ja tavoitesuuntautuneella ohjauksella. Itse asiassa viimeaikainen tutkimus viittaa siihen, että projektipäälliköiltä ja projektiryhmäläisiltä odotetaan entistä itsenäisempää, analyyttisempaa ja riskejä paremmin sietävää ammattilaisuutta epävarmassa ympäristössä. Työskentely projekteissa on tulossa organisaatioiden kannalta entistä strategisemmaksi, mikä vaatii strategista tilanteen oivaltamista, tiivistä suhdetta yhteistyötahoihin ja kykyä koordinoida monimutkaista kokonaisuutta (Ahola 2009; Aaltonen 2010; Dietrich 2007; Martinsuo \& Lehtonen 2009; Martinsuo et al. 2010). Tarve luovia esimiehen ja projektipääl-

Kuva 2. Projektien toimijoiden roolit ja ohjauksen asema eri rooleissa

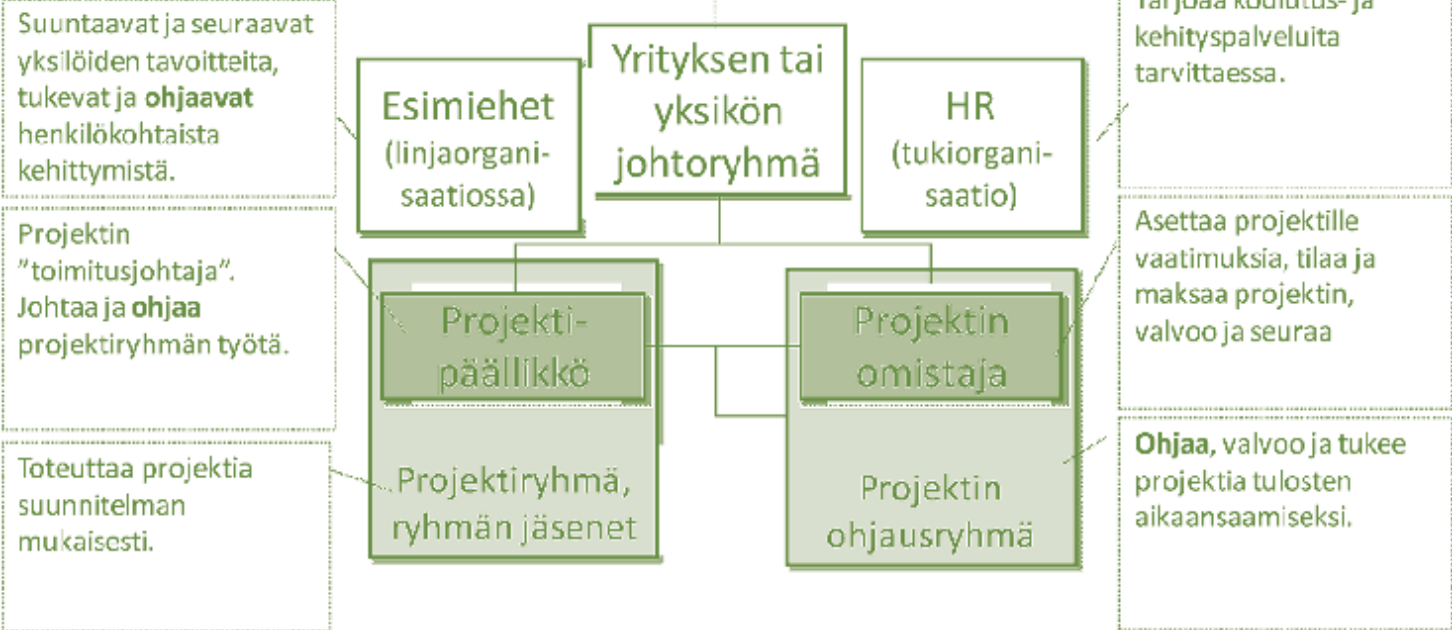


likön toisinaan ristiriitaisten vaatimusten keskellä merkitsee, että yksilöohjaukselle saattaa olla hetkellisiä ja pitkäkestoisiakin odotuksia, joita projektien tavanomaiset ohjausjärjestelyt eivät käytännössä täytä.

\section{Projektimaisen työn ohjaustilanteiden ryhmittely}

Osa projektimaisen työn ohjauksellisista tarpeista liittyy työntekijä̈n itseensä projektimaisessa työssä, hänen työkykyynsä sekä suhteisiinsa muihin ihmisiin. Edellä korostui myös se, että ihmisen vuorovaikutussuhteissa teknologialla on entistä keskeisempi merkitys modernissa työelämässä. Projektiryhmässä tai ohjausryhmän kanssa työskentely, suhde projektipäällikköön, asiakkaaseen ja linjaesimieheen, projektinhallintaosaaminen, IT-järjestelmien käyttö, tuotanto- ja prosessiteknologian parissa ja aikapaineessa työskentely ovat esimerkkejä tavanomaisista yksilötason asioista, joihin voi liittyä monenlaisia ohjaustarpeita.

Organisaation ja laajemman verkoston perustehtävä samoin voi herättää erilaisia ohjauksellisia tarpeita. Edellä käsittelin sitä, että moniprojektiympäristössä ja monitiimiprojekteissa toimiessaan työntekijöillä on emo-organisaatiotaan laajemmat kytkennät ulkopuolisiin toimijoihin, jolloin myös perustehtävä itsessään saattaa vaihdella projektista, tehtävästä ja organisaatiosta toiseen. Näin ollen esimerkiksi projektin identiteetti omassa organisaatiossa tai imago asiakkaan silmissä, asiakasorganisaation toimintaajatus, verkoston elinkelpoisuus ja jatkuvuus, oman organisaation projektivalintaperiaatteet, verkoston eri organisaatioiden prosessit ja toimintamallit sekä monet muut ilmiöt voivat aiheuttaa erilaisia organisaation perustehtävään liittyviä ohjaustarpeita.

Edelleen työntekijän oma perustehtävä ja sen erityisyys projektimaisessa työssä voi olla varsin epäselvä ja moninainen ja synnyttää monenlaisia ohjaustarpeita. Muiden muassa oman ajankäytön priorisointi omien projektien välillä, henkilökohtaiset pitemmän aikajänteen tavoitteet, eri projektien erilaiset osaamisvaatimukset, projektien elinkaaren vaihe, projektien organisatoriset kytkennät, resursointi, aikataulutus, rahoitus ja monet muut yksittäisiin projekteihin ja projektien muodostamaan kokonaisuuteen liittyvät asiat voivat nousta esiin ohjaustilanteissa olennaisina ilmiöinä.

Monet näistä ohjaustarpeista voidaan ratkaista tavoitteisiin suuntautuvan ohjauksen keinoin ja tavanomaisten projektiohjausvoimavarojen puitteissa. Lisäksi kuitenkin projektimaisessa työssä voi ilmetä nimenomaan projektien ja projektimaisen toiminnan dynamiikkaan, epävarmuuteen ja tietovajeisiin liittyviä, hetkessä olevia, erityisen akuutteja ilmiöitä, joissa työntekijä voi kaivata ohjausta. Esimerkiksi aloitteleville projektipäälliköille ongelma- ja muutostilanteet, poikkeamat suunnitelmista, projektin sisäiset ristiriidat ja kiireelliset vaatimukset vaikkapa ohjausryhmästä tai asiakkaalta syntyvät projektien arjessa ja edellyttävät nopeaa ratkaisua.

Kokeneemmilla projektipäälliköillä ja etenkin moniprojektiympäristössä toimivilla henkilöillä erilaiset projektien väliset periaatteet - esimerkiksi resurssien jakamiseen, aikatauluun, teknologian yhteiskäyttöön, ihmisten globaaliin siirtymiseen liittyen - ja konfliktit ovat tilanteessa herääviä, nopeasti ratkaisua tarvitsevia ilmiöitä.

Suurten muutosohjelmien johtajilla ja avainhenkilöillä monia akuutteja ohjaustarpeita voi liittyä etenkin ohjelman toteuttamiseen emoorganisaatio(i)ssa sekä ohjelman osaprojektien ja emo-organisaation väliseen vuorovaikutukseen. Projektityössä myös kriisit ja kysymykset projektin tai ohjelman keskeyttämisestä ovat mahdollisia ja voivat aiheuttaa ohjaustarpeita. Nämä hankalammat ja tilannesidonnaiset asiat eivät välttämättä sisälly projektien tavanomaiseen ohjauskäytäntöön, ja projektipäälliköillä tai ohjausryhmillä ei välttämättä ole valmiuksia vastata niihin liittyviin ohjaustarpeisiin.

Kuvassa 3 esitetään projektimaisessa työssä ohjauksen kannalta oleellisia asioita ja tilanteita sekä työnohjauksen mahdollinen rooli tavanomaista projektiohjausta täydentävänä ohjausmuotona.

\section{Työnohjaukselliset ratkaisut projektimaisen työn erilaisille ohjaustilanteille}

Nykyisellään projektien johto- tai ohjausryhmän tai valvojan rooliin ei yleensä kuulu työnohjauksellista tehtävää, vaikka monenlaista tukea projektimaisessa työssä usein kaivataan. Osa työnohjauksellisesta 
Kuva 3. Erilaisia ohjaustarpeita, - näkökulmia ja -tapoja projektimaisessa työssä

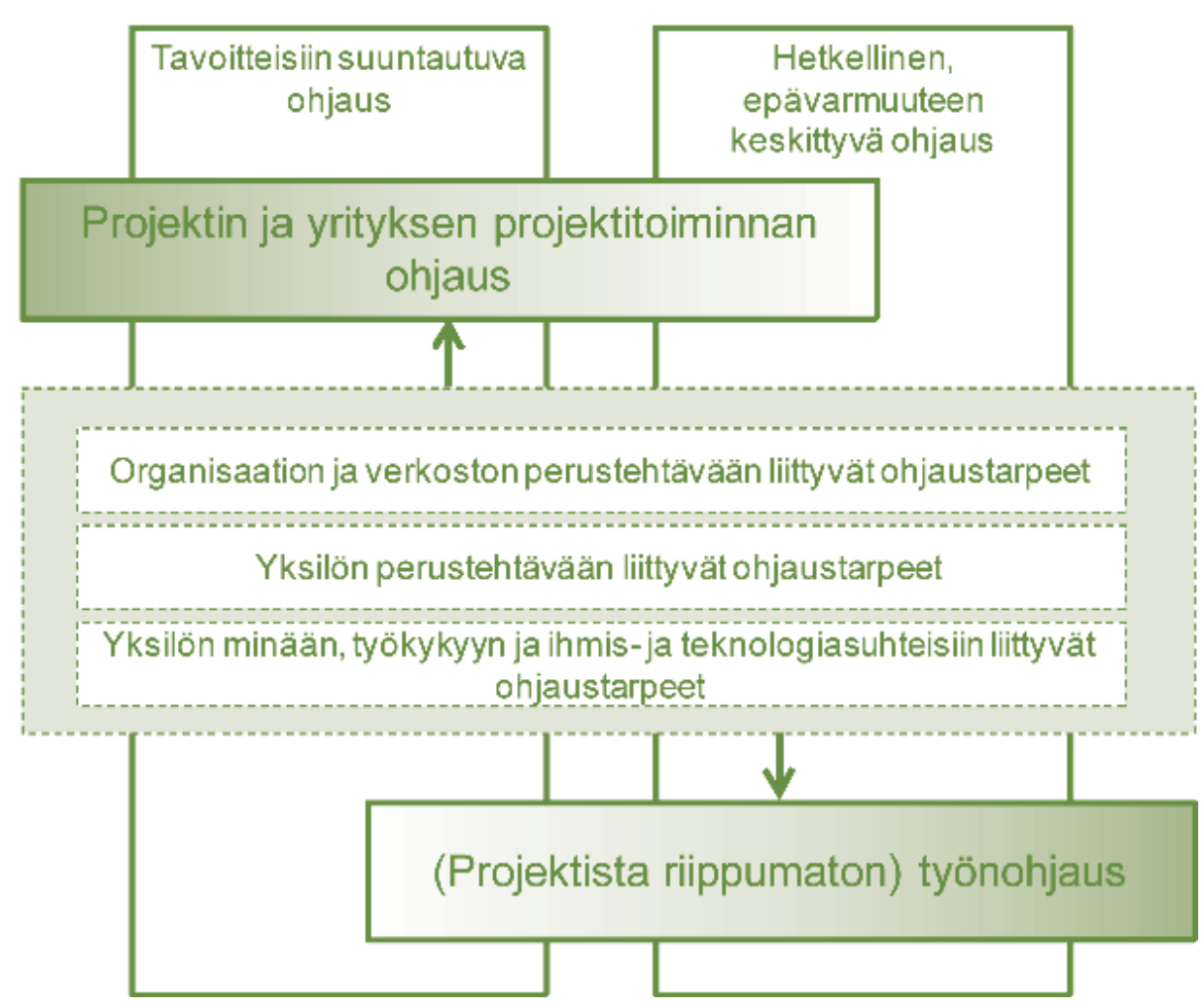

tarpeesta voitaisiin toteuttaa laajentamalla nimetyn valvojan tai ohjausryhmän jäsenen roolia sisältämään enemmän ohjauksellisia tehtäviä, ehkä suuntautuen joko työssä selviytymisen, ammatillisen kehittymisen, työn uudistamisen tai akuuttien tilanteiden ratkaisun erityishaasteisiin. Joissakin yrityksissä onkin käytössä mentorointia, jossa esimerkiksi kokeneempi projektipäällikkö tukee ja ohjaa aloittelevaa projektipäällikköä oman toimensa ohessa (joskin usein ilman varsinaista ohjaajapätevyyttä). Joissakin yrityksissä on käytössä projektipäälliköiden vertaisverkostoja (tms. "käytännön yhteisöjä", osaamisverkostoja), joissa osittaista ohjaustukea on ainakin hetkellisesti tarjolla.

Edelleen suomalaisetkin yritykset ovat ottaneet käyttöön niin sanottuja projektitoimistoja, jotka tarjoavat ohjeistusta ja neuvontaa projektien henkilöstön tarpeisiin. Työnohjauksellinen, organisaatioiden sisäinen tuki projektimaisessa työssä on yleisesti ottaen kuitenkin varsin satunnaista, kokeiluluontoista ja perustuu oman toimen ohessa tapahtuvaan vapaaehtoiseen ja epämuodolliseen lähestymistapaan. Työnohjaukseen keskittyvää, pätevää ohjaustukea voisi projekti- maisessa työssä olla selvästi nykyistä enemmän.

Ammattimaisella, ulkopuolisella työnohjauksella voisi olla sija projektimaisen työn tukemisessa erityisesti sen akuuteissa, ongelmallisissa ja ryhmä- ja organisaatiorajat ylittävissä ohjaustarpeissa. Tavanomaiset projektikoulutukset eivät tarjoa keinoja työn haasteissa selviytymiseen, ne ovat riittämätön keino tukea ammatillista kehittymistä ja niiden kautta ei puututa lainkaan työn uudistamiseen ja akuuttien tilanteiden ratkaisuun. Pääpaino aiemmassa työnohjauskirjallisuudessa on selvästi ollut pitkäkestoisessa tai tavoitteellisessa, ajallisesti rajatussa työnohjauksessa, mikä voi nopealiikkeisessä, globaalissa projektitoiminnassa osoittautua haasteeksi. Työ ei välttämättä ole säännöllistä, se ei välttämättä tapahdu samassa paikassa tai edes tietyssä maassa, sen vaativuus ja haasteet vaihtelevat päivästä ja viikosta toiseen ja sen puitteet voivat muuttua jatkuvasti. Kohdennettu työnohjaus projektimaisessa työssä edellyttäisi kekseliäitä ratkaisuja pitkäkestoisen, terapeuttisen ja kasvattavan työnohjauksen rinnalle, jotta työn dynaamisuuden ja epävarmuuden vaatimukset tulisi otettua huomioon.

Esimerkiksi voisi kokeilla lyhyitä, tavoitteellisia 
ohjausratkaisuita liittyen työn tilanteeseen (kuten tiettyyn projektin vaiheeseen tai projektikokonaisuuden kypsyysvaiheeseen), tiettyihin ammatillisiin ja uran siirtymiin (kuten siirryttäessä pienestä projektista vaativampiin tai useampiin projekteihin) tai monimutkaisten kokonaisuuksien selkiyttämiseen (kuten projektiverkoston hahmottaminen tai projektin tuotteen määrittely). Internet-välitteisiä tai tiiviitä, kertaluontoisia työpajamaisia akuuttiohjausratkaisuja voisi kehittää apukeinoiksi ajassa oleviin ongelmiin, konflikteihin ja kriiseihin. Edelleen projektien johtamis- ja ohjausmalleihin voisi nykyistä paremmin sisällyttää työnohjauksellisia elementtejä, joiden kautta henkilöstön kaipaama tuki olisi organisoidusti saatavilla muuttuvien työtilanteiden edellyttämällä tavalla. Projektimaisen työn akuuteissa ohjaustarpeissa oleellisia ovat $\mathrm{mm}$. seuraavat asiat:

- Työssä olevan tilanteen nopea hahmottaminen ja ohjauksen kohdentaminen tilanteessa olevaan tarpeeseen llähinnä onko kyse jostain tietystä projektista vai projektien muodostamasta kokonaisuudesta ja onko kyse organisaation sisäisestä vai ulkopuolisesta asiastal

- Ohjauksen kytkeytyminen suoraan työssä oleviin ilmiöihin ja sitä kautta nopea sovellettavuus työssä lesimerkiksi visuaaliset, toiminnalliset ja draamalliset menetelmät ja tilanteiden mallinnus/simulointi työnohjauksen keinoinal

- Ohjattavan oman aktiivisuuden ja vaikutusmahdollisuuksien vahvistaminen (toisin sanoen suora ohjaus - toteutetun työn seuranta ja sitä kautta työn kehittäminen)

- Harkinta siitä, tarvitaanko erillistä, ulkopuolista työnohjausta vai voidaanko olemassa olevia ohjausjärjestelmiä suunnata enemmän työnohjaukselliseen työskentelyyn lesimerkiksi projektin ohjausryhmä, valvoja, työntekijöiden esimiehet)

Etenkin ohjauksen kohdentaminen oikeaan tarpeeseen ja nopea vaikuttaminen työssä antavat vihjeen siitä, että työnohjauksessa voitaisiin käyttää apukeinoina jo nyt olemassa olevia, projektimaiselle työlle ominaisia välineitä ja menetelmiä. Esimerkiksi projektinhallinnan, strategiatyöskentelyn, sidosryh- mäsuhteiden hallinnan ja verkostosuunnittelun jo olemassa olevia välineitä ja menetelmiä voitaisiin käyttää akuutin työnohjaustilanteen määrittelyssä ja jäsentämisessä ja sitä kautta työhön sisältyvien ongelmien ja ilmiöiden ratkaisemisessa.

\section{PÄÄTELMÄT}

Tämä artikkeli lähti liikkeelle kysymyksestä, millä tavoin projektimaista työtä voidaan tukea työnohjauksen keinoin. Projektimainen työ kuvattiin modernin työelämän dynaamisten organisaatioiden tavanomaisena, toistuvana ja toimintaa monimuotoistavana todellisuutena. Jos työnohjaus on perinteisesti olettanut organisaatioilta ja yksilöiltä vakaata ja määriteltävissä olevaa perustehtävää ja keskittynyt työpaikan sosiaalisten suhteiden käsittelyyn, projektimaisessa työssä on hyväksyttävä perustehtävän dynaamisuus ja epämääräisyys ja käsiteltävä myös teknologiaan ja muihin organisaatioihin liittyviä suhteita.

Projektimaisen työn ohjaustilanteita ryhmittämällä havaittiin, että perinteisiä työnohjausmalleja täydentäen projektimaisessa työssä on erityisen paljon sellaisia akuutteja, työtilanteessa hetkellisesti ilmeneviä tilanteita, joissa projektien henkilökunta kaipaa ohjauksellista tukea asioiden nopeaksi ratkaisemiseksi. Haasteeksi havaittiin, että liikkuvan ja jatkuvasti muuttuvan työn olosuhteet eivät välttämättä salli pitkäkestoisia ohjaussuhteita. Sen sijaan akuuttien ohjaustarpeiden ratkaisuun tarvittaisiin nopeampia, lyhytkestoisempia ja heti työsuorituksessa vaikuttavia keinoja.

Keskeisenä tuloksena ehdotin projektimaisen työn tilanteen selkeää määrittelyä ohjaustarpeen ymmärtämiseksi, eri ohjaustapojen ja -tahojen tarkoituksenmukaista käyttöä eri tilanteiden ohjaustarpeissa ja projektimaisen työn oman apuvälineistön valjastamista työnohjauksen tarpeisiin. Lisäksi tunnistin luontevan mahdollisuuden jakaa moninaiset työnohjaustehtävät projektin olemassa olevien tukitahojen ja ammattimaisten työnohjaajien kesken ja esitin joitakin ideoita nimenomaan projektimaisen työn työnohjaukseen soveltuvista toteutustavoista. Käytännön kehitystoimenpiteitä edellyttänee se, että harva projektiammattilainen 
kouluttautuu ohjauksen ammattilaiseksi ja harva ammattimainen työnohjaaja ymmärtää projektimaisen työn erityishaasteita.

Jatkoselvitysaiheena olisi mielekästä tehdä perusteellinen analyysi olemassa olevista tutkimuksista projektimaisten ja muiden asiantuntijatöiden ohjauksen kohdalla (sis. työnohjaus ja muut ohjausmuodot). Lisäksi projektipäälliköiden ja -ammattilaisten ohjauskokemuksista ja työnohjauksen todellisista tarpeista olisi hyvä tehdä empiirinen tutkimus, jotta työnohjausratkaisuja voitaisiin kehittää todellisiin tarpeisiin. Koska tässä ydinehdotukset eli projektimaisen työn oma apuvälineistö ja sen työnohjaukselliset sovellukset, ehdotukset lyhytkestoisten ohjausten toteutukseen ja ohjausvastuiden uudelleenmäärittely on esitetty kovin tiiviisti, eri osa-alueiden täsmentäminen vaatii jatkokehittelyä ja tarkentamista.

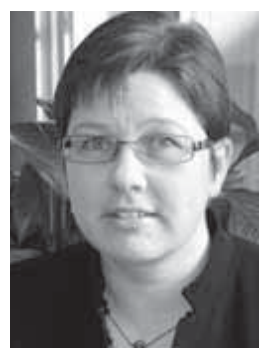

Miia Martinsuo

TkT, professori,

Teollisuustalous

Tampereen teknillinen yliopisto

\section{LÄHTEET}

Aaltonen, K. (2010). Stakeholder management in international projects. Aalto University, School of Science and Technology, Department of Industrial Engineering and Management. Doctoral Dissertation Series 2010/13. Espoo, Finland.

Ahola, T. (2009). Efficiency in project networks: the role of inter-organizational relationships in project implementation. Aalto University, School of Science and Technology, Department of Industrial Engineering and Management. Doctoral Dissertation Series 2009/10. Espoo, Finland.

Artto, K., Martinsuo, M., Dietrich, P. and Kujala, J. (2008). Project strategy - strategy types and their contents in innovation projects. International Journal of Managing Projects in Business, 1(1), 49-70.

Artto, K., Martinsuo, M. and Kujala, J. (2006). Projektiliiketoiminta. 1. painos. WSOY Oppimateriaalit Oy.
Engwall, M. (2003). No project is an island: linking projects to history and context. Research Policy 32: 789-808.

Dietrich, P. (2007). Coordination strategies in organizational development programs. Helsinki University of Technology, Laboratory of Industrial Management, Doctoral dissertation series 2007/3. Espoo.

Ibarra, H. (2003). Working identity. Unconventional strategies for reinventing your career. Harvard Business School Press.

Julkunen, R. (2008). Uuden työn paradoksit. Keskusteluja 2000-Luvun työprosess(e)ista. Tampere: Vastapaino.

Lehtonen, P. and Martinsuo, M. (2009). Integrating the change program with the parent organization. International Journal of Project Management, 27(2). 154-165.

Lundin, R.A. and Söderholm, A. (1995). A theory of the temporary organisation. Scandinavian Journal of Management, 11(4), 437-455.

Malone T. W. (2004). The future of work. How the new order of business will shape your organization, your management style, and your life. Harvard Business School Press.

Martinsuo M., Aaltonen K. \& Lehtonen P. (2010). Project autonomy in complex delivery projects: Taking and withdrawing autonomy in systems and turnkey deliveries. In: Wald, Andreas et al. (Eds.) Advanced project management, 95-118. Germany: Deutsche Gesellschaft für Projektmanagement.

Martinsuo, M. and Lehtonen, P. (2009). Project autonomy in complex service development networks. International Journal of Managing Projects in Business, 2(2), 261-281.

Niskanen, P., Sorri, P. \& Ojanen, M. (1988). Auta auttamaan - käsikirja työnohjauksesta.

Pinchot, G. \& Pinchot, E. (1993). The end of bureaucracy and the rise of the intelligent organization. BerrettKoehler Publishers.

Seppänen, J. (2004). Hullu työtä tekee. Helsinki: Otava.

Siltala, J. (2004). Työelämän huonontumisen lyhyt historia. Helsinki: Otava.

Vartiainen, M., Lönnblad, J., Balk, A. \& Jalonen, K. (2005). Mobiilin työn haasteet. Työpoliittinen tutkimus, nro 269. Helsinki: Työministeriö.

Vartiainen, M., Ruuska, I. \& Kasvi, J.J.J. (2003). Projektiosaaminen - dynaamisen organisaation voimavara. Tampere: Teknologiateollisuus.

Zika-Viktorsson, A., Sundström, P. \& Engwall, M. (2006). Project overload: An exploratory study of work and management in multi-project settings. International Journal of Project Management, 24, 385-394. 